Bioresursy i pryrodokorystuvannya - Bioresources and nature use, 6, 1-2, 131-137 [in Ukrainian].

7. Roslynnytstvo Ukrainy. Statystychnyi zbirnyk, 2017 [Crop production of Ukraine. Statistical yearbook, 2017]. (2018). Kyiv: Derzhavna sluzhba statystyky Ukrayiny [in Ukrainian].

8. Plaksyuk, L.B., Vdovychenko, A.V., \& Ternovyj, Yu.V. (2017). Ocinka gerbologichnoyi sytuaciyi na posivax soyi u perexidnomu periodi do organichnogo zemlerobstva v umovax zminy klimatu [Assessment of the herbological situation on soybean crops in the transitional period to organic farming under conditions of climate change]. Zbalansovane pryrodokorystuvannya - Balanced natural resources, 1 , 123-127 [in Ukrainian].

9. Minkova, O.G., Sakalo, V.M., \& Gorb, O.O. (2016). Markuvannya ta sertyfikaciya organichnoyi produkciyi [Marking and Certification of Organic Products]. Aktualni problemy ekonomiky - Current Problems of Economics, 2, 126-135 [in Ukrainian].

10. Hadzalo, Ya.M., \& Kamins'kyy, V.F. (Eds.). (2016). Naukovi osnovy vyrobnytstva orhanichnoyi produktsiyi v Ukrayini [Scientific basis of organic pro- duction in Ukraine]. Kyiv: Ahrarna nauka [in Ukrainian].

11. Babych, A.A., Nyemtsov, A.V., \& Petrychenko, V.F. (2000). Naukovi osnovy suchasnykh tekhnolohii vyroshchuvannia soi na nasinnia v umovakh Lisostepu Ukrainy [Scientific bases of modern technologies of soybean cultivation for seeds in the conditions of the forest-steppe of Ukraine]. Zbirnyk naukovyk hprats' Vinnyts'koho DAU - Collection of scientific works of Vinnytsia State Veterinary Academy, 7, 10-13 [in Ukrainian].

12. Vereshchagin, L.N. (2001). Vrediteli i bolezni zernooyh kolosooyh kul'tur [Pests and diseases of cereal crops ]. Kyiv: YUnivest Marketing [in Ukrainian].

13. Rudenko, V.M. (2012). Matematychna statystyka: navchalnyj posibnyk [Mathematical statistics: a manual]. Kyiv: Centr uchbovoyi literatury [in Ukrainian].

14. Parfeniuk, A.I. (2017). Sort roslin yak chinnik biologichnoyii bezpeki v agrotsenozi [Plant varieties as a factor in biosafety agrocenoses]. Ahroekolohichnyi zhurnal - Ahroecological journal, 2, 155-163 [in Ukrainian].

\title{
ВПЛИВ СІРКИ НА ЯКІСТЬ ЗЕРНА ПШЕНИЦІ ОЗИМОЇ
}

\author{
В.Ф. Голубченко, Е. В. Куліджанов
}

\section{Одеська фрілія ДУ «Інститут охорони грунтів України»}

\begin{abstract}
Наведено результати вивчення впливу сірки на грунти, рослини і якість зерна пшениці озимої за сумісної дії з азотом, фосфором і магнієм. Найістотніше підвищення вмісту сірки в грунті порівняно з контролем було зафіксовано у шарі 0-25 см у 2006 i 2007 рр. за норми 60 кг/га - на 297,2-332,8\%. Засвоєння рослинами пшениці сірки, азоту, фосфору і калію у всі фази розвитку виявилось оптимальним у 2007 р., що сприяло формуванню зерна за показниками: вмісту білка, кількості і якості клейковини, осипання, скловидності, натури на рівні вимог першого класу.
\end{abstract}

Ключові слова: сірка, азот, фосфор, магній, чорноземи південні, пшениця озима, якість зерна.

Грунти Одеської обл. мають, в основному, нейтральну і слаболужну реакцію грунтового розчину, мало адсорбують сульфати і можуть втрачати їх від вимивання. Ранньою весною у всіх грунтах мінеральна сірка, як і азот, є в дефіциті, тому всі озимі культури позитивно реагують в цей період на її внесення [1]. Відомо, що сірка є необхідним компонентом білків, вітамінів, багатьох інших з'єднань і тому входить до

В.Ф. Голубченко, Е. В. Куліджанов, 2018 складу основних поживних елементів, засвоюється рослинами у вигляді сульфатів. Основні її запаси містяться у складі органічної речовини, лише 10-20\% у мінеральній формі [2]. Рухомі форми сірки в грунті, подібно до нітратів, під час танення снігу і випадання опадів вимиваються з верхніх у нижні горизонти грунту. Тому вміст сірки в шарі $0-25$ см може характеризувати грунти як бідні на цей мезоелемент, натомість основні їі за- 
паси накопичуються у нижніх горизонтах. Отже, найбільш точним буде визначення вмісту сірки в рослинах. Урожайність і якість зерна пшениці озимої знижуються, якщо грунти недостатньо забезпечені сіркою. Активна діяльність мікроорганізмів у грунті щодо розкладання органічної речовини сприяє вивільненню сірки з органічної у мінеральну форму: за аеробних умов переважно у сульфати, а за анаеробних - у сульфіди. Процес мінералізації сірки відбувається подібно до нітрифікації азоту й протікає паралельно [3, 4]. Потрібно враховувати також зворотний процес перетворення сірки, азоту, фосфору, магнію у органічні форми в організмі бактерій, що тимчасово виводить ї зі складу рухомих з'єднань. Такий процес було зафіксовано нами в дослідах, коли у фазу колосіння пшениці зменшився вміст азоту в грунті, а у фазу молочно-воскової стиглості зерна вміст нітратного азоту знову підвищився [5]. Науковці [6] також відзначають, що між валовим умістом $\mathrm{N}, \mathrm{P}, \mathrm{K}$ у рослинах за фазами їх розвитку і якістю зерна існує кореляційний зв'язок, який найбільш точно визначає рівень білка і клейковини у фазу колосіння пшениці озимої на середніх суглинках. Метою досліду є вивчення сумісної дії сірки з азотом, фосфором та магнієм на грунти і якісні показники зерна пшениці озимої.

\section{МАТЕРІАЛИ ТА МЕТОДИ ДОСЛІДЖЕНЬ}

Польовий дослід проводили у 20052008 рр. за схемою: 1) без добрив, 2) доломитове борошно (фон, ф), 3$) \phi+\mathrm{N}_{46}$, 4) $\left.\left.\phi+\mathrm{N}_{46} \mathrm{~S}_{20}, 5\right) \phi+\mathrm{N}_{46} \mathrm{~S}_{40}, 6\right) \phi+\mathrm{N}_{46} \mathrm{~S}_{60}$, 7) $\left.\left.\phi+\mathrm{N}_{92}, 8\right) \phi+\mathrm{N}_{92} \mathrm{~S}_{20}, 9\right) \phi+\mathrm{N}_{92} \mathrm{~S}_{40}$, 10) $\left.\left.\phi+\mathrm{N}_{92} \mathrm{~S}_{60}, 11\right) \phi+\mathrm{N}_{138}, 12\right) \phi+\mathrm{N}_{138} \mathrm{~S}_{20}$, 13) $\left.\left.\phi+\mathrm{N}_{138} \mathrm{~S}_{40}, 14\right) \phi+\mathrm{N}_{138} \mathrm{~S}_{60}, 15\right) \phi+$ $\left.\left.\mathrm{N}_{184} \mathrm{~S}_{60}, 16\right) \phi+\mathrm{N}_{92} \mathrm{P}_{60}, 17\right) \phi+\mathrm{N}_{92} \mathrm{P}_{60} \mathrm{~S}_{20}$, 18) $\left.\phi+\mathrm{N}_{92} \mathrm{P}_{60} \mathrm{~S}_{40}, 19\right) \phi+\mathrm{N}_{92} \mathrm{P}_{60} \mathrm{~S}_{60}$, 20) $\phi+\mathrm{N}_{184} \mathrm{P}_{120} \mathrm{~S}_{60}$.

Грунти дослідної ділянки - чорноземи південні малогумусні важкосуглинкові на лесах. Загальна площа дослідної ділянки $64 \mathrm{~m}^{2}$, облікова - $48 \mathrm{м}^{2}$. Повторність - триразова, розміщення варіантів - у три яруси зі зміщенням. Застосовували такі добрива: доломитове борошно, карбамід, елементарну сірку, а з 2006 р. - амофос вносили під допосівну культивацію. Визначали: вміст азоту у грунті (за ГОСТ 26951-86), рухомих сполук фосфору і калію (за ДСТУ 4114-2002), сірки (за ГОСТ 26490-85); у рослинах: азот, фосфор, калій, сірку, клейковину за ДСТУ, чинними в Україні. У досліді використовували сорт пшениці Шестопаловка. Врожай пшениці озимої обліковували прямим комбайнуванням. Дію сірки на грунти і рослини вивчали сумісно з азотом і фосфором на магнієвому фоні у фази розвитку і такі періоди: перед внесенням у грунти, у фази кущення, колосіння, молочно-воскової і повної стиглості зерна.

\section{РЕЗУЛЬТАТИ ТА ЇХ ОБГОВОРЕННЯ}

У Одеській обл. площа грунтів з низьким і дуже низьким умістом сірки становить 40,8\%, що негативно впливає на врожайність і, особливо, якість зернових культур. До груп грунтів з низьким та дуже низьким умістом сірки входять чорноземи південні $-51,7$ тис. га, чорноземи звичайні 112,1 , чорноземи типові - 75,8 тис. га. Лише 13,4\% грунтів області мають високий і дуже високий уміст сірки, що свідчить про необхідність внесення сірчаних добрив на переважній більшості площ.

За нашими дослідженнями внесення елементарної сірки в комплексі з азотом, магнієм і фосфором у середньому за 4 роки підвищило її вміст порівняно $з$ контролем у шарі грунту 0-25 см залежно від норм внесення: 20 кг га - на 33,0\%, 40 - на 81,2, 60 - на $127,3 \%$, а в шарі 25-50 см - на 23,9; 67,3; 109,8\% відповідно. Найістотніше підвищення вмісту сірки було зафіксовано у верхньому 0-25 см шарі - на 297,2332,8\% - у 2006 і 2007 pp. за норми внесення 60 кг/га; у нижньому 25-50 см шарі менше на 25,3-124,2\% відповідно. Трансформацію вмісту сірки в грунті зумовлено використанням мезоелемента рослинами, його міграцією у горизонти нижче ніж 50 см, втратами у газоподібній формі, можливою фіксацією мікроорганізмами, i навпаки. На вміст мезоелемента у грунті впливали також періодичні посухи. 
Засвоєння сірки рослинами у всі роки досліджень у фазу кущення виявилось оптимальним [7]. У фазу колосіння вміст сірки був визначений як високий - у 2006 i 2008 рр. і оптимальний - у 2007 р. У фазу молочно-воскової стиглості в рослинах і повної стиглості в зерні вміст сірки у 2007 р. перевищував відповідні показники інших років у варіантах з використанням добрив: за норми 20 кг/га - на 0,06-0,09\%, 40 - на 0,07-0,09, 60 кг га на $0,07-0,16 \%$, що відобразилось на підвищенні якості зерна.

Внесення сірки у нормі 20 кг/га сприяло підвищенню в зерні білка: у 2005 р. на $0,5 \%$, у 2006 - на 0,2 , у 2007 - на 1,6 , у 2008 р. - на 1,3\%; за норми 40 кг/га - на 0,$7 ; 0,0 ; 1,5 ; 1,4 \% ; 60$ кг га - на 0,$7 ; 0,5 ; 1,5$; 1,0\% відповідно. Найісточніше підвищення вмісту білка в зерні пшениці за дії сірки зафіксовано у посушливий 2007 р., окрім варіанта 2 (з внесенням доломитового борошна), коли у фазу кущення було виявлено низький уміст фосфору, а у фазу колосіння - низький уміст азоту. У всіх варіантах досліду за показниками вмісту білка, кількості і якості клейковини, осипання, скловидності і за натурою зерно пшениці урожаю 2007 р. відповідало вимогам першого класу. В умовах помірної зволоженості 2005 р. у трьох варіантах, а у 2008 р. у всіх варіантах, за вмістом білка зерно відповідало вимогам другого класу; за вологих умов 2006 р. у варіанті 19 (ф+ $\left.\mathrm{N}_{92} \mathrm{P}_{60} \mathrm{~S}_{60}\right)$ - вимогам другого, у інших варіантах - третього класу.

\section{ВИСНОВКИ}

Уміст сірки в грунті підвищувався відповідно до збільшення норм внесення і був однаковим в обох досліджуваних шарах. Найвищі показники підвищення вмісту сірки у грунті були зафіксовані в умовах посушливого 2007 р. у фазу молочно-воскової стиглості зерна пшениці озимої, нижчі за помірно зволожених умов 2005 і 2008 pp. (зі зниженням вмісту мезоелемента у фазу молочно-воскової стиглості), а також рівномірне забезпечення грунтів сіркою увесь період вегетації за вологого 2006 р. Унесення сірки сприяло підвищенню засвоєння рослинами азоту на $2,0-8,7 \%$, фосфору - на 2,3-16,7, калію - на 2,3-19,9\%. Оптимальними для формування якості зерна пшениці озимої на чорноземах південних були показники 2007 р.: вміст сірки у рослинах у фазу кущення становив $0,17-$ $0,22 \%$, азоту - 4,7-5,3, фосфору - 0,350,40 , калію - 3,6-4,1\%; у фазу колосіння 0,15-0,19; 3,3-3,6; 0,22-0,26; 2,4-2,7\% відповідно. Упродовж усіх років досліджень показники якості зерна пшениці озимої у варіантах із внесенням сірки були покращені, зокрема стосовно вмісту білка і клейковини. Вирішальною фазою для накопичення білка і отримання клейковини високої якості виявилась фаза молочно-воскової стиглості (або флагового листа), за якої у 2007 р. рослини були оптимально забезпечені сіркою, а в зерні їі було найбільше за усі роки досліджень. Зерно пшениці у 2007 р. за всіма визначеними показниками відповідало вимогам першого класу.

\section{ЛІТЕРАТУРА}

1. Хоменко О.Д. Сірчане живлення і продуктивність культурних рослин / О.Д. Хоменко // Вісник сільськогосподарської науки. - 1980. - № 9. C. $17-20$.

2. Городній M.I. Агрохімія: Підручник / М.I. Городній, А.В. Бикін, Л.М. Нагаєвська. - К.: Алефа, 2003. $-786 \mathrm{c}$

3. Удобрения, их свойства и способы использования / Под ред. Д.А. Коренькова. - М., 1982. - 415 с.

4. Выходиев B.A. Резерв повышения урожайности и качества зерна / В.А. Выходцев // Агрохимический вестник. -2005 . - № 2. - С. 6-8.

5. Голубченко В.Ф. Дія добрив на нітрифікаційну здатність грунтів в посівах озимої пшениці в Сте- пу України / В.Ф. Голубченко, Е.В. Куліджанов // Вісник Харківського національного аграрного університету імені В.В. Докучаєва. - 2016. № 2. - С. 93-99. - (Серія «Грунтознавство, агрохімія, землеробство, лісове господарство, екологія грунтів»).

6. Захаров В.Н. Управление качеством зерна озимой пшеницы с помощью методов оперативной почвенной и растительной диагностики / В.Н. Захаров, А.А. Коваленко // Агрохимия. 1992. - № 5. - С. 47-56.

7. Церлинг В.В. Диагностика питания сельскохозяйственных культур / В.В. Церлинг. - М.: Агропромиздат, 1990. - 235 с. 


\title{
REFERENCES
}

1. Khomenko, O.D. (1980). Sirchane zhyvlennia i produktyvnist kulturnykh roslyn [Sulfur nutrition and productivity of cultivated plants]. Visnyk silskohospodarskoi nauky - Bulletin of Agricultural Science, 9, 17-20 [in Ukrainian].

2. Horodnii, M.I. Bykin, A.V. Nahaievska, L.M. (2003). Ahrokhimiia: Pidruchnyk [Agrochemistry: Textbook]. Kyiv: Alefa [in Ukrainian].

3. Korenkova, D.A. (Ed.). (1982). Udobreniya, ikh svoystva I sposoby ispolzovaniya [Fertilizers, their properties and methods of use]. Moskva [in Russian].

4. Vykhodtsev, V.A. (2005). Rezerv povysheniya urozhaynosti i kachestvazerna [Reserve for increasing the yield and quality of grain]. Agrokhimicheskiy vestnik - Agrochemical Bulletin 2, 6-8 [in Russian].

5. Holubchenko, V.F. (2016). Diia dobryv na nitryfikatsiinu zdatnist gruntiv v posivakh ozymoi pshe- nytsi v Stepu Ukrainy [Effect of fertilizers on the nitrification capacity of soils in winter wheat crops in the Steppe of Ukraine].Visnyk Kharkivskoho natsionalnoho ahrarnoho universytetu imeni V.V. Dokuchaieva - Bulletin of the Kharkov National Agrarian University named after V.V. Dokuchaev, 2, 93-99 [in Ukrainian].

6. Zakharov, V.N. Kovalenko, V.N. (1992). Upravleniye kachestvom zerna ozimoy pshenitsy s pomoshchyu metodov operativnoy pochvennoy I rastitelnoy diagnostiki [Management of quality of winter wheat grain with the help of methods of operative soil and vegetative diagnostics]. Agrokhimiya - Agrochemicals, 5, 47-56 [in Russian].

7. Tserling, V.V. (1990). Diagnostika pitaniya selskokhozyaystvennykh kultur [Diagnosis of nutrition of agricultural crops]. Moskva: Agropromizdat [in Russian].

\section{ВПЛИВ СТРОКІВ СІВБИ НА ПРОДУКТИВНІСТЬ ВАЛЕРІАНИ ЛІКАРСЬКОЇ}

\author{
Н.В. Приведенюк, Л.А. Глущенко, В.А.Трубка \\ Дослідна станція лікарських рослин ІАП НААН
}

\begin{abstract}
Проведено аналіз температурного режиму та тривалості вегетації валеріани лікарської в умовах Лівобережного Лісостепу. Визначено оптимальні строки сівби валеріани лікарської в осінній період та встановлено їх вплив на ріст, розвиток та продуктивність культури. Обгрунтовано, що для успішної перезимівлі посівів рослини повинні сформувати розетку з 3-5 справжніх листків до настання стабільно низьких температур. За накопичення суми активних температур (вище $\left.5^{\circ} \mathrm{C}\right)$ упродовж осіннього періоду понад $1126^{\circ} \mathrm{C}$ частина рослин валеріани після перезимівлі вступає в генеративну фазу, що негативно впливає на формування врожайності кореневищ з коренями. Встановлено, що із збільшенням періоду вегетації продуктивність валеріани лікарськоі підвищується, а період вегетації в 266 діб забезпечує максимальну врожсайність сухих кореневищ, з коренями.
\end{abstract}

Ключові слова: валеріана лікарська, строки сівби, кореневища з коренями, врожайність, сума ефективних температур.

Рослина може повністю розкрити свої генетичні можливості щодо формування високоякісного врожаю лише за умов оптимального забезпечення всіма факторами життя - світлом, теплом, вологою, повітрям та поживними речовинами у процесі вегетації [1]. Підвищення продуктивності сільськогосподарських культур нерозрив-

(C) Н.В. Приведенюк, Л.А. Глущенко, В.А.Трубка, 2018 но переплітається з оцінкою агрокліматичних ресурсів території та раціональним їх використанням. Зміни умов навколишнього природного середовища, які спостерігаються останніми роками, спричиняють зміни рівня продуктивності сільськогосподарських культур.

Особливо це стосується останнього десятиліття, що відрізняється найбільшими проявами змін клімату, зокрема підвищен- 